\title{
Clostridium scatologenes strain SL1 isolated as an acetogenic bacterium from acidic sediments
}

\author{
Kirsten Küsel, ${ }^{1}$ Tanja Dorsch, ${ }^{1}$ Georg Acker, ${ }^{2}$ Erko Stackebrandt ${ }^{3}$ \\ and Harold L. Drake ${ }^{1}$
}

Author for correspondence: Kirsten Küsel. Tel: +49 921555 642. Fax: +49 921555799.

e-mail: kirsten.kuesel@bitoek.uni-bayreuth.de

1,2 Department of Ecological Microbiology, BITOEK ${ }^{1}$, and Division of Biological Sciences, Electron Microscopy Laboratory, University of Bayreuth², 95440 Bayreuth, Germany

3 Deutsche Sammlung von Mikroorganismen und Zellkulturen $\mathrm{GmbH}$, 38124 Braunschweig, Germany

\begin{abstract}
A strictly anaerobic, $\mathrm{H}_{2}$-utilizing bacterium, strain $\mathrm{SL1}$, was isolated from the sediment of an acidic coal mine pond. Cells of strain SL1 were sporulating, motile, long rods with a multilayer cell wall. Growth was observed at 5-35 ${ }^{\circ} \mathrm{C}$ and $\mathrm{pH}$ 3.9-7.0. Acetate was the sole end product of $\mathrm{H}_{2}$ utilization and was produced in stoichiometries indicative of an acetyl-CoA-pathway-dependent metabolism. Growth and substrate utilization also occurred with $\mathrm{CO} / \mathrm{CO}_{2}$, vanillate, syringate, ferulate, ethanol, propanol, 1-butanol, glycerine, cellobiose, glucose, fructose, mannose, xylose, formate, lactate, pyruvate and gluconate. With most substrates, acetate was the main or sole product formed. Growth in the presence of $\mathrm{H}_{2} / \mathrm{CO}_{2}$ or $\mathrm{CO} / \mathrm{CO}_{2}$ was difficult to maintain in laboratory cultures. Methoxyl, carboxyl and acrylate groups of various aromatic compounds were 0 -demethylated, decarboxylated and reduced, respectively. Small amounts of butyrate were produced during the fermentation of sugars. The acrylate group of ferulate was reduced. Nitrate, sulfate, thiosulfate, dimethylsulfoxide and Fe(III) were not utilized as electron acceptors. Analysis of the 16 S rRNA gene sequence of strain SL1 demonstrated that it is closely related to Clostridium scatologenes $(99.6 \%$ sequence similarity), an organism characterized as a fermentative anaerobe but not previously shown to be capable of acetogenic growth. Comparative experiments with C. scatologenes DSM $757^{\top}$ demonstrated that it utilized $\mathrm{H}_{2} / \mathrm{CO}_{2}$ (negligible growth), $\mathrm{CO} / \mathrm{CO}_{2}$ (negligible growth), formate, ethanol and aromatic compounds according to stoichiometries indicative of the acetyl-CoA pathway. CO dehydrogenase, formate dehydrogenase and hydrogenase activities were present in both strain SL1 and C. scatologenes DSM 757'. These results indicate that (i) sediments of acidic coal mine ponds harbour acetogens and (ii) $\mathrm{C}$. scatologenes is an acetogen that tends to lose its capacity to grow acetogenically under $\mathrm{H}_{2} / \mathrm{CO}_{2}$ or $\mathrm{CO} / \mathrm{CO}_{2}$ after prolonged laboratory cultivation.
\end{abstract}

Keywords: Clostridium scatologenes, acetogenesis, carbon monoxide dehydrogenase, Gram-positive bacteria, acid mine ponds

\section{INTRODUCTION}

Acetogenic bacteria are obligate anaerobes that use the acetyl-CoA pathway and reduce $\mathrm{CO}_{2}$ to acetate as their main product of respiration (Wood \& Ljungdahl, 1991; Drake, 1994). Most acetogens have been isolated from strictly anaerobic habitats like marine or estuarine sediments, freshwater ponds or anoxic sewage

The EMBL accession number for the 16S rRNA gene sequence of strain SL1 is $Y 18813$. sludge (Drake, 1994; Schink, 1994). Phylogenetically they do not form a distinct unit, but are intermixed within the large phylogenetic group of Gram-positive clostridia (Tanner \& Woese, 1994). Based on comparative 16S rRNA gene sequence analyses and phenotypic data, the extremely heterogeneous genus Clostridium was taxonomically restructured and new nomenclature for many acetogens was proposed (Collins et al., 1994; Willems \& Collins, 1995, 1996). According to the taxonomic rearrangement, acetogens are present in eight different clusters (Willems \& 
Collins, 1996). Based on their phylogenetic proximity, closely related clostridial and acetogenic species might possess similar physiological capabilities.

In this study, an $\mathrm{H}_{2}$-utilizing acetogen, isolate SL1, was isolated from an acidic sediment. Analysis of the 16S rRNA gene sequence of SL1 indicated that the isolate was closely related to Clostridium scatologenes. Comparative evaluation of C. scatologenes DSM $757^{\mathrm{T}}$ revealed that it was capable of acetogenic growth and contained $\mathrm{CO}$ dehydrogenase, indicating that $C$. scatologenes should be classified as an acetogen.

\section{METHODS}

Field site and sampling. Sediments were obtained from an acidic coal mine pond located in the Lusatian mining area in east central Germany. The $\mathrm{pH}$ of the lake water and of the upper iron-rich sediment was approximately 3 and $3 \cdot 2$, respectively. The maximum summer temperature of the upper sediment was $12{ }^{\circ} \mathrm{C}$. No oxygen was detected at the water/sediment interface. Replicate sediment cores were collected in February 1997 with a gravity corer in plexiglas tubes (i.d. $5.9 \mathrm{~cm}$ ), transported to the laboratory and sectioned under an $\mathrm{N}_{2}$ atmosphere within $24 \mathrm{~h}$.

Enrichment cultures. Upper sediment from five replicate cores was pooled under anoxic conditions and $40 \mathrm{~g}$ (fresh wt) sediment was transferred to sterile $150 \mathrm{ml}$ infusion bottles (Merck) inside a Mecaplex anaerobic chamber $\left(100 \% \mathrm{~N}_{\text {}}\right.$ gas phase). Bottles were closed with rubber stoppers and screw-cap seals, flushed with sterile argon for $15 \mathrm{~min}$ and incubated in the dark at $12{ }^{\circ} \mathrm{C}$ with an initial overpressure of $20-25 \mathrm{kPa}$ argon at room temperature for $90 \mathrm{~d}$. Sterile $\mathrm{H}_{2}$ [28 mmol (1 culture $)^{-1}$ ] was added as electron donor. After the complete consumption of $\mathrm{H}_{2}$, aliquots of the sediment were added to anaerobic FePPi medium [approx. $1 \mathrm{~g}$ sediment to $9 \mathrm{ml}$ medium (see below)]. The enrichment cultures were supplemented with $\mathrm{H}_{2}$ [28 mmol (l culture $)^{-1}$ ] and incubated at $15^{\circ} \mathrm{C}$. After two transfers, enrichment cultures were streaked onto solid U medium [solidified with $1.5 \%$ agar (see below)]. Isolated colonies were transferred to and maintained in liquid $U$ medium for assessment of substrate/product profiles. Cultures were considered to be pure based on uniform colony and cell morphologies.

Composition of media. Anaerobic media were prepared by the modified Hungate technique (Hungate, 1969). FePPi medium (Caccavo et al., 1994) contained $\left(1^{-1}\right): \mathrm{NaHCO}_{3}$, $2.5 \mathrm{~g} ; \mathrm{NH}_{4} \mathrm{Cl}, 1.5 \mathrm{~g} ; \mathrm{KH}_{2} \mathrm{PO}_{4}, 0.6 \mathrm{~g} ; \mathrm{KCl}, 0.1 \mathrm{~g}$; yeast extract, $0.5 \mathrm{~g}$; vitamins (Drake, 1994), $10 \mathrm{ml}$; trace metals (Drake, 1994), $10 \mathrm{ml}$; soluble ferricpyrophosphate $\left[\mathrm{Fe}_{4}\left(\mathrm{P}_{2} \mathrm{O}_{7}\right)_{3}\right], 3 \mathrm{~g}$. The gas phase was $\mathrm{N}_{2} / \mathrm{CO}_{2}(80: 20, \mathrm{v} / \mathrm{v})$; the final $\mathrm{pH}$ of the medium was approximately 6.7 . U medium is a non-reduced, undefined medium and contained $\left(1^{-1}\right): \mathrm{NaHCO}_{3}, 7 \cdot 5 \mathrm{~g} ; \mathrm{KH}_{2} \mathrm{PO}_{4}, 0.5 \mathrm{~g} ; \mathrm{MgCl}_{2}$. $6 \mathrm{H}_{2} \mathrm{O}, 0.05 \mathrm{~g}$; $\mathrm{NaCl}, 0.4 \mathrm{~g} ; \mathrm{NH}_{4} \mathrm{Cl}, 0.4 \mathrm{~g} ; \mathrm{CaCl}_{2} .2 \mathrm{H}_{2} \mathrm{O}, 0.01 \mathrm{~g}$; yeast extract, $1.0 \mathrm{~g}$; B vitamin solution (Drake, 1994), $5.0 \mathrm{ml}$; trace element solution (Drake, 1994), $5.0 \mathrm{ml}$. The gas phase was $100 \% \mathrm{CO}_{2}$ and the $\mathrm{pH}$ after autoclaving was approximately 6.9. TSB medium contained tryptic soy broth (Difco), without dextrose, at a final concentration of $2.75 \mathrm{~g} \mathrm{l}^{-1}$; the initial $\mathrm{pH}$ of the medium was adjusted to different values, as indicated. The gas phase was $100 \% \mathrm{~N}_{2}$. Substrates were added as sterile stock or as sterile gas. For substrate utilization studies, most substrates were added at an initial concentration of 5-10 $\mathrm{mM}$; sodium formate and ethanol were added at 25 and $15 \mathrm{mM}$, respectively. The concentrations of $\mathrm{H}_{2}$ and $\mathrm{CO}$ were as indicated. Unless otherwise indicated, the incubation temperature was $30^{\circ} \mathrm{C}$.

Analytical techniques. Headspace gases were measured with Hewlett Packard 5980 series II gas chromatographs (Küsel \& Drake, 1995). Gas values included the total amounts in both liquid and gas phases. In this study, no distinction was made between $\mathrm{CO}_{2}$ and its carbonate forms. Concentrations were corrected for the changing liquid/gas phase volume ratio due to liquid samplings $(0.5 \mathrm{ml})$. Aliphatic acids, aromatic compounds, alcohols and sugars were determined with Hewlett Packard 1090 series II high-performance liquid chromatographs (Küsel \& Drake, 1995). Nitrate and sulfate were analysed by ion chromatography (Küsel \& Drake, 1995). Reduction of Fe(III) was determined visually by a change of the yellow medium to colourless and the formation of a white $\mathrm{Fe}(\mathrm{II})$ carbonate precipitate, and also analytically by measuring the accumulation of $\mathrm{Fe}(\mathrm{II})$. $\mathrm{Fe}(\mathrm{II})$ was measured by the phenanthroline method (Tamura et al., 1974). The $\mathrm{pH}$ was measured with an Ingold U457-S7/110 combination $\mathrm{pH}$ electrode. Growth was monitored as $\mathrm{OD}_{660}$ with a Spectronic 501 spectrophotometer (Bausch and Lomb). Protein content was determined by the method of Bradford (1976).

Electron microscopy. Strain SL1 was cultivated at $30{ }^{\circ} \mathrm{C}$ in $\mathrm{U}$ medium supplemented with fructose $(10 \mathrm{mM})$. Cells were fixed by adding glutaraldehyde to a final concentration of $2 \%(\mathrm{v} / \mathrm{v})$ and harvested by centrifugation. For negative staining (Valentine et al., 1968), an aqueous solution of uranyl acetate $(2 \%, \mathrm{w} / \mathrm{v} ; \mathrm{pH} 4 \cdot 6)$ was used. For thin-section preparations, pelleted cells were embedded in agar $(2 \%$, $\mathrm{w} / \mathrm{v}$ ) and fixed in glutaraldehyde $/ \mathrm{OsO}_{4}$ (Traub et al., 1976). After staining for 7 min with $2 \%$ uranyl acetate and, subsequently, for $5 \mathrm{~min}$ with lead citrate (Reynolds, 1963), specimens were examined in a model CEM 902A microscope (Zeiss).

Preparation of cell extract and enzyme assays. Cells were cultivated in $\mathrm{U}$ medium supplemented with either ethanol $(10 \mathrm{mM})$ or vanillate $(10 \mathrm{mM})$. Cultures were centrifuged and the cell pellet was washed and incubated in lysozyme buffer as described previously (Kuhner et al., 1997). Hydrogenase and $\mathrm{CO}$ dehydrogenase activities were assayed at $30{ }^{\circ} \mathrm{C}$ in anaerobic Tris $/ \mathrm{HCl}$ buffer $(100 \mathrm{mM}, \mathrm{pH} 8.5)$ containing $1 \mathrm{mM}$ benzyl viologen and $1 \mathrm{mM}$ dithiothreitol; the gas phase was $100 \% \mathrm{H}_{2}$ for hydrogenase assays and $100 \%$ CO for CO dehydrogenase assays (Drake, 1982a).

Preparation and redox difference spectra of membranes. Cells were cultivated in $U$ medium supplemented with fructose $(10 \mathrm{mM})$. Membranes were prepared from cell extracts by ultracentrifugation under aerobic conditions (Fröstl et al., 1996). Washed membranes were reduced with sodium dithionite and reduced-minus-oxidized spectra were obtained with a model Uvikon 930 double-beam recording spectrophotometer (Kontron Instruments) at room temperature.

SDS-PAGE. Cells were cultivated in U medium supplemented with either fructose $(10 \mathrm{mM})$, vanillate $(10 \mathrm{mM})$ or lactate $(10 \mathrm{mM})$ and cell extracts were prepared by lysozyme digestion for electrophoretic analysis. Preparation of gels and one-dimensional electrophoresis were according to standard protocols (Laemmli, 1970).

Isolation and $\mathbf{G}+\mathbf{C}$ content of DNA. DNA was isolated by standard methods (Cashion et al., 1977). The G+C content of the DNA was determined by HPLC (Mesbah et al., 1989). 

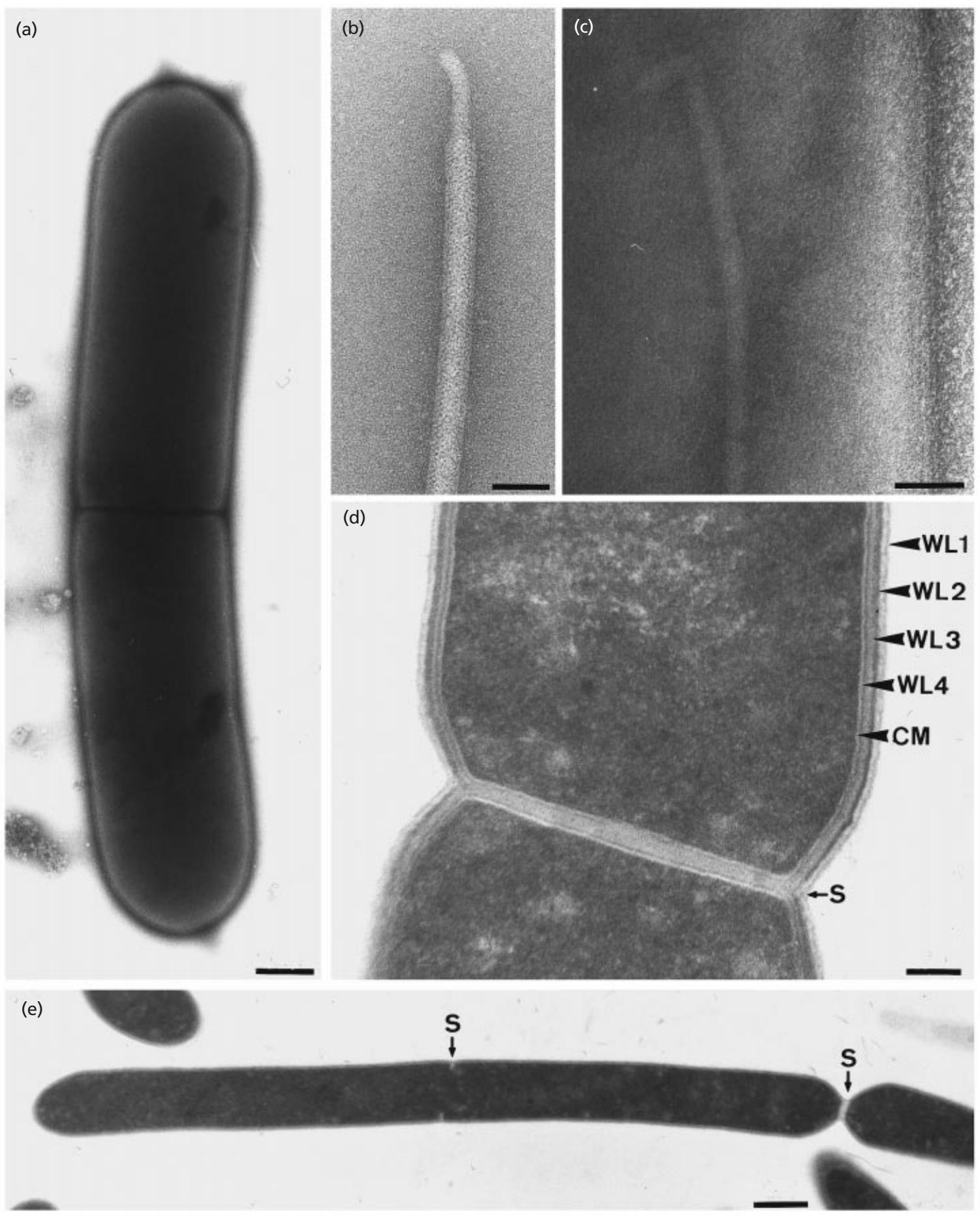

Fig. 1. Electron micrographs of strain SL1. (a-c) Negatively stained cells showing (a) cell division, (b) an isolated flagellum revealing the flagellar filament and hook, and (c) a laterally inserted flagellum. (d, e) Thin section micrographs of dividing cells. Bars: $0.5(a, e), 0.1$ (c, d) and $0.05 \mu \mathrm{m}(\mathrm{b})$. WL, cell wall layer; CM, cytoplasmic membrane; S, septum.

16S rRNA gene sequencing and construction of the dendrogram. Genomic DNA was extracted, amplified by PCR and purified (Rainey et al., 1996). Purified PCR products were sequenced by using an ABI PRISM Ready Reaction Dye Terminator kit (Applied Biosystems). Sequence reaction mixtures were electrophoresed with an
Applied Biosystems model 373A DNA sequencer. Alignments of the sequence were done manually and determination of similarity values were done by the ae 2 editor (Maidak et al., 1996). Phylogenetic dendrograms were constructed according to the method of DeSoete (1983) and by the neighbour-joining method contained in the PHYLIP 
package (Felsenstein, 1993; Saitou \& Nei, 1987). Bootstrap analysis was used to evaluate the tree topology of neighbourjoining data by performing 500 resamplings (Felsenstein, 1985). Accession numbers of reference organisms are included in Fig. 4.

\section{RESULTS}

\section{Enrichment and isolation of strain SL1}

Enrichment cultures in FePPi medium consumed supplemental $\mathrm{H}_{2}$ within $7 \mathrm{~d}$ and produced acetate. $\mathrm{Fe}$ (III) was not reduced. After three subsequent transfers in liquid FePPi medium, the enrichment was streaked onto solidified U medium. A colony was picked and serially diluted in liquid $U$ medium. The consumption of supplemental $\mathrm{H}_{2}$ occurred within $3 \mathrm{~d}$ in all growth-positive dilutions and was coincident with the production of acetate. The mean $\mathrm{H}_{2}$ /acetate ratio was approximately $4 \cdot 2: 1$, a value indicative of $\mathrm{H}_{2}$-dependent acetogenesis (Wood \& Ljungdahl, 1991; Drake, 1994). Isolate SL1 was obtained after consecutively restreaking (three times) an isolated colony obtained from the highest positive dilution. Colonies were shiny, convex, beige and had a maximum diameter of 3-4 mm.

\section{Morphology of strain SL1}

Isolate SL1 was a motile, long, thin rod (Fig. 1). Single cells were 3-4 $\mu \mathrm{m}$ in length; chains of cells were up to $10 \mu \mathrm{m}$ long (Fig. 1e). Flagellar staining (Blenden \&
Goldberg, 1965) and electron microscopy revealed peritrichous flagella. Cells were motile in wet mounts. In old cultures, terminal and free spores were observed. Cells stained weakly Gram-negative (Clark, 1973) and thin sections revealed a multilayer cell wall (Fig. 1d).

\section{General growth properties of strain SL1}

Isolate $\mathrm{SL} 1$ grew at $5-35^{\circ} \mathrm{C}$; no growth was observed at $40{ }^{\circ} \mathrm{C}$. Rates and yields of growth were optimal at $25-30{ }^{\circ} \mathrm{C}$. Growth was observed after a sporulated culture was heated for $15 \mathrm{~min}$ at $80^{\circ} \mathrm{C}$. In U medium at $\mathrm{pH} 6.8$ supplemented with fructose $(10 \mathrm{mM})$, the doubling time at both 25 and $30^{\circ} \mathrm{C}$ was approximately $5.3 \mathrm{~h}$. Growth could not be maintained in U medium lacking yeast extract. In TSB medium strain SL1 grew at $\mathrm{pH} 3 \cdot 9-7 \cdot 0$. No growth was observed at $\mathrm{pH} 3.4$ and 7.8. Rates and yields of growth were optimal at $\mathrm{pH} 5 \cdot 8$ to 6.9 . No growth or substrate consumption were observed in the presence of oxygen. In U and TSB medium, strain SL1 produced a dung-like odour similar to skatole. When grown on tryptophan in $\mathrm{U}$ medium, the skatole-like odour was more intense.

\section{Substrate range and fermentation stoichiometries of strain SL1}

In $\mathrm{U}$ medium, the following substrates were utilized: cellobiose, glucose, fructose, xylose, arabinose, mannose, vanillate, syringate, ferulate, ethanol, propanol, 1-butanol, glycerine, lactate, gluconate, pyruvate, for-

Table 1. Acetate/substrate stoichiometry of strain SL1 and C. scatologenes DSM $757^{\top}$ cultivated in U medium

\begin{tabular}{|c|c|c|c|c|c|c|}
\hline Organism & Substrate & $\begin{array}{c}\text { Total } \\
\text { incubation } \\
\text { time (h) }\end{array}$ & $\Delta O D_{660} *$ & $\begin{array}{c}\text { Substrate } \\
\text { consumed } \\
(\mathrm{mM}) \dagger\end{array}$ & $\begin{array}{c}\text { Acetate } \\
\text { produced } \\
(\mathbf{m M})\end{array}$ & $\begin{array}{c}\text { Acetate/substrate } \\
\text { ratio } \S\end{array}$ \\
\hline \multirow[t]{8}{*}{ Strain SL1 } & Fructose & 50 & $0 \cdot 90$ & $8 \cdot 5$ & $20 \cdot 3$ & $2 \cdot 39(3)$ \\
\hline & Arabinose & 50 & $0 \cdot 79$ & $8 \cdot 1$ & $19 \cdot 8$ & $2 \cdot 44(2 \cdot 5)$ \\
\hline & Ethanol & 120 & $0 \cdot 15$ & $16 \cdot 8$ & $23 \cdot 8$ & $1 \cdot 42(1 \cdot 5)$ \\
\hline & Formate & 100 & $0 \cdot 17$ & $26 \cdot 3$ & $6 \cdot 9$ & $0.26(0 \cdot 25)$ \\
\hline & Pyruvate & 50 & $0 \cdot 21$ & $1 \cdot 7$ & $2 \cdot 1$ & $1 \cdot 24(1 \cdot 25)$ \\
\hline & Vanillate & 100 & $0 \cdot 18$ & $9 \cdot 2$ & $7 \cdot 2$ & $0.78(0.75)$ \\
\hline & $\mathrm{H}_{2}$ & 380 & $0 \cdot 06$ & $28 \cdot 0$ & $8 \cdot 0$ & $0.29(0 \cdot 25)$ \\
\hline & $\mathrm{CO}$ & 380 & $0 \cdot 08$ & $27 \cdot 6$ & $7 \cdot 3$ & $0 \cdot 26(0 \cdot 25)$ \\
\hline \multirow[t]{7}{*}{ C. scatologenes } & Fructose & 50 & $0 \cdot 79$ & $8 \cdot 4$ & $15 \cdot 4$ & $1 \cdot 83(3)$ \\
\hline & Arabinose & 50 & $0 \cdot 69$ & $7 \cdot 8$ & $15 \cdot 6$ & $2 \cdot 00(2 \cdot 5)$ \\
\hline & Ethanol & 120 & ND & $11 \cdot 8$ & $11 \cdot 8$ & $1 \cdot 00(1 \cdot 5)$ \\
\hline & Formate & 100 & ND & $24 \cdot 3$ & $3 \cdot 3$ & $0 \cdot 14(0 \cdot 25)$ \\
\hline & Vanillate & 100 & $0 \cdot 12$ & $8 \cdot 4$ & $5 \cdot 8$ & $0.69(0.75)$ \\
\hline & $\mathrm{H}_{2}$ & 2000 & Negligible $\|$ & $15 \cdot 4$ & $3 \cdot 1$ & $0 \cdot 20(0 \cdot 25)$ \\
\hline & $\mathrm{CO}$ & 2900 & Negligible $\|$ & $27 \cdot 1$ & $3 \cdot 9$ & $0 \cdot 14(0 \cdot 25)$ \\
\hline
\end{tabular}

* Values are corrected for the $\Delta \mathrm{OD}_{660}$ in controls lacking additional substrates. ND, Not determined.

$\dagger$ Values are the mean of two or three replicates.

$\$$ Values are corrected for the amount of acetate formed in controls lacking additional substrates.

$\S$ Values in parentheses are the theoretical acetate/substrate ratios.

|| During the first $2 \mathrm{~d}$, growth was similar to controls lacking substrate and then levelled off. 
Table 2. Effect of different media on the product profiles of strain SL1 and C. scatologenes DSM $757^{\top}$ cultivated on sugars

The initial concentration of sugars was $10 \mathrm{mM}$ and decreased to non-detectable levels after $3 \mathrm{~d}$ incubation.

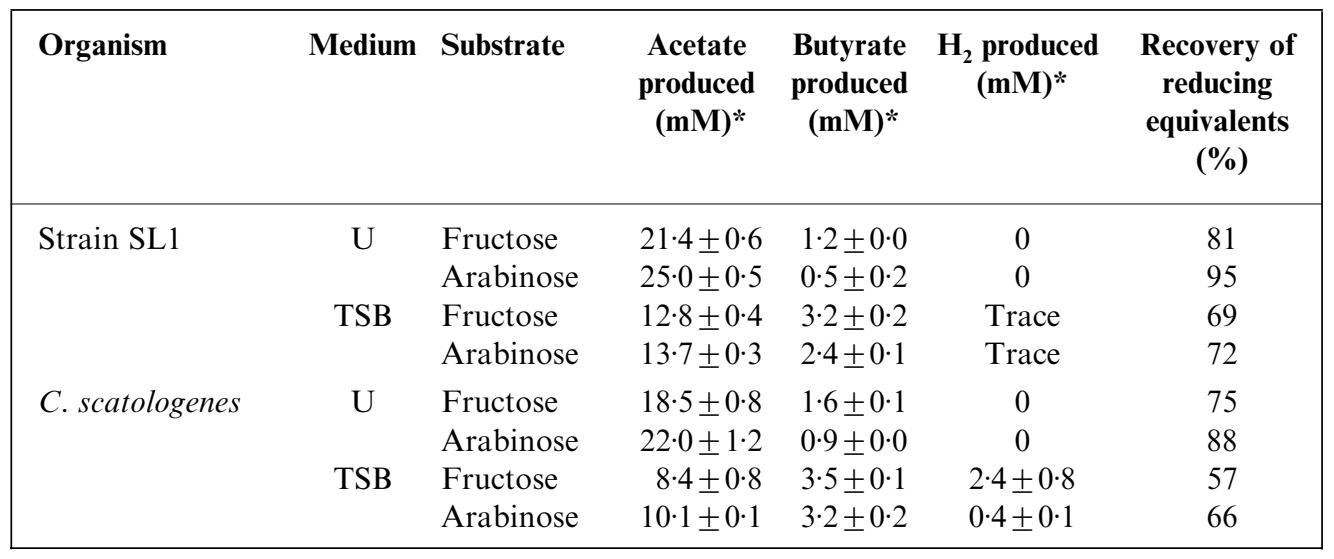

* Values are the mean $( \pm \mathrm{SD})$ of three replicates and are corrected for the amount of product formed in controls lacking additional substrates. Trace, non-quantifiable levels detected.

mate, $\mathrm{H}_{2} / \mathrm{CO}_{2}$ and $\mathrm{CO} / \mathrm{CO}_{2}$. In all cases, optical densities were greater than those observed in the absence of supplemental substrates and acetate was the major end product (Table 1 and data not shown). Butyrate was also formed during the fermentation of sugars. In TSB medium, strain SL1 produced higher amounts of butyrate than in U medium (Table 2). Products formed from yeast extract or TSB were acetate, butyrate and iso-valerate. Neither growth nor substrate utilization were observed with melizitose, saccharose, lactose, maltose, galactose, trimethoxybenzoate, 4-hydroxybenzaldehyde, methanol, 2,3butanediol, succinate, fumarate, citrate, oxalate, glyoxylate, acetate or butyrate.

Vanillate was O-demethylated and decarboxylated to catechol (Fig. 2a). When fructose and protocatechuate were provided simultaneously as substrates, protocatechuate was decarboxylated to catechol during fructose consumption (Fig. 2b). The aromatic ring recovery was approximately $95 \%$, indicating that the aromatic ring was not subject to further transformation. The vanillate/acetate ratio was approximately $4: 3 \cdot 1$ (Table 1), a value indicative of vanillate-dependent acetogenesis (Drake, 1994). Syringate was sequentially O-demethylated to 5-hydroxyvanillate and gallate (data not shown).

\section{Maintenance of $\mathrm{H}_{2}$ and CO cultures of strain SL1}

The capacity of strain SL1 to utilize $\mathrm{H}_{2}$ and $\mathrm{CO}$ decreased with prolonged cultivation. For example,

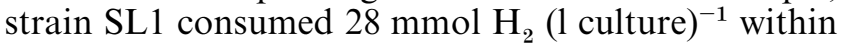
$5 \mathrm{~d}$ of when it was originally isolated and grown under $\mathrm{H}_{2}$; this time increased to 4 weeks after six sequential transfers under $\mathrm{H}_{2}$. In contrast, the capacity of strain SL1 to utilize aromatic compounds was stable in maintained cultures.

\section{Reduction of alternative electron acceptors by strain SL1}

Ferulate was reduced to hydroferulate and further Odemethylated to hydrocaffeate (Fig. 3). When isolate SL1 was grown in the presence of nitrate $(5 \mathrm{mM})$, nitrate was not utilized and acetate production was not appreciably affected, indicating that nitrate is not used as an alternative electron acceptor. Similar results were obtained with sulfate, thiosulfate, dimethylsulfoxide and $\mathrm{Fe}(\mathrm{III})$, indicating that they too were not used as alternative electron acceptors.

\section{Enzyme activities and redox difference spectra of membranes of strain SL1}

The $\mathrm{CO}$ dehydrogenase activities in cell extracts obtained from fructose-, vanillate- and ethanol-cultivated cells was approximately $0 \cdot 3,3 \cdot 8$ and $6 \cdot 3 \mu \mathrm{mol}$ $\min ^{-1}$ (mg protein) $)^{-1}$, respectively (Table 3 ). Hydrogenase and formate dehydrogenase activities in extracts of ethanol-grown cells were greater than those of fructose- and vanillate-grown cells (Table 3). No absorption maxima indicative of a type $b$ or type $c$ cytochrome were detected in the membrane or cytoplasmic fraction of strain SL1 (data not shown).

\section{S rRNA gene sequence and $G+C$ content of strain SL1}

Phylogenetic analysis of the almost complete $16 \mathrm{~S}$ rRNA gene sequence $(93.3 \%$ of the Escherichia coli sequence) with the database of $16 \mathrm{~S}$ rRNA gene sequences (Maidak et al., 1996) indicated that strain SL1 is a member of the low G+C Gram-positive bacteria. The highest sequence similarity value $(99.6 \%$ ) was to C. scatologenes (Fig. 4); the similarities 

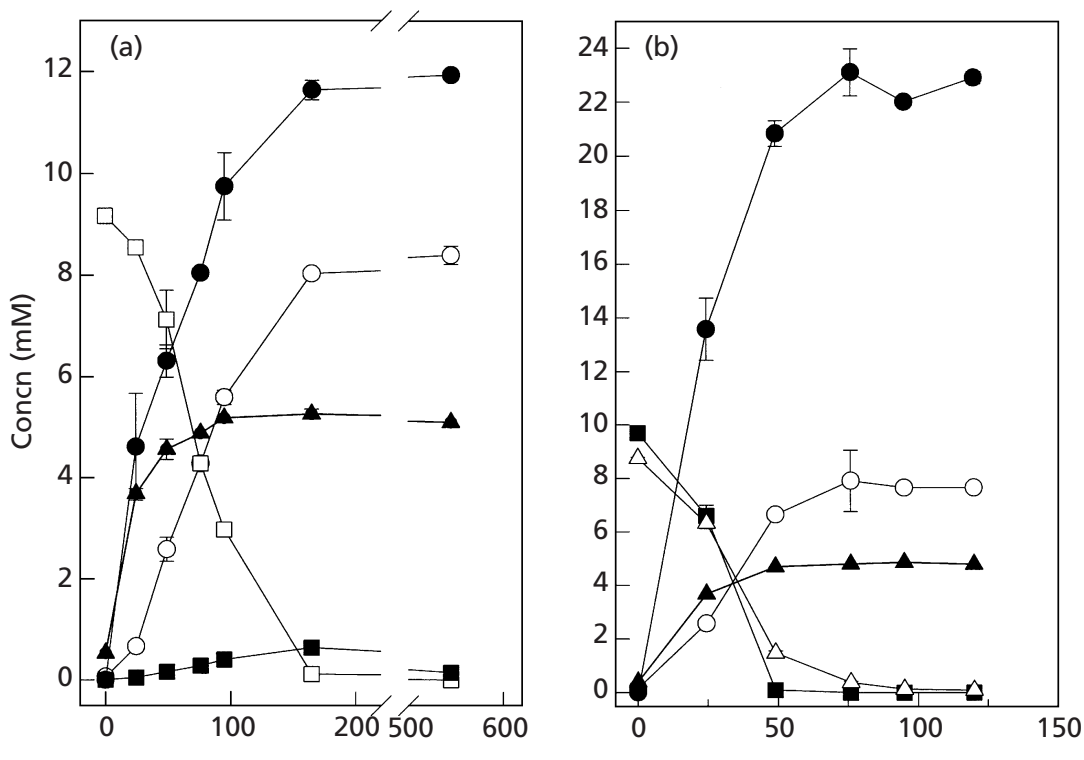

Fig. 2. Substrate/product profiles of strain SL1 cultivated in $U$ medium supplemented with vanillate (a) and with fructose and protocatechuate (b). Data are the means ( \pm SD) of three replicates. $\square$, Vanillate; $\mathbf{\square}$, protocatechuate; $\bigcirc$, catechol; $\boldsymbol{O}$, acetate; $\Delta$, fructose, $\Delta$ acetate in controls lacking additional substrate. of strain SL1 to Clostridium magnum and Clostridium pasteurianum were 95.1 and $93.8 \%$, respectively. The DNA $\mathrm{G}+\mathrm{C}$ content of strain SL1 was $30.3 \mathrm{~mol} \%$. The $\mathrm{G}+\mathrm{C}$ content of $C$. scatologenes is $27 \mathrm{~mol} \%$ (Johnson \& Francis, 1975).

\section{Comparative protein profiles of SL1 and C. scatologenes DSM 757}

Cells of strain SL1 and of C. scatologenes DSM 757 that had been cultivated on fructose, lactate or vanillate yielded nearly identical protein profiles when cell extracts were subjected to SDS-PAGE analysis (data not shown).

\section{Comparative evaluation of the acetogenic capacities of C. scatologenes DSM $757^{\top}$}

Based on the 16S rRNA gene sequence and protein profile similarities between strain SL1 and C. scatologenes, C. scatologenes DSM $757^{\mathrm{T}}$ was analysed for its acetogenic capacities. In U medium, $C$. scatologenes DSM $757^{\mathrm{T}}$ grew slower than strain SL1. C. scatologenes DSM $757^{\mathrm{T}}$ grew more rapidly and produced higher cell yields in TSB medium compared to $\mathrm{U}$ medium. C. scatologenes DSM $757^{\mathrm{T}}$ utilized the following substrates in U medium: cellobiose, glucose, fructose, arabinose, mannose, vanillate, ethanol, 1butanol, lactate, pyruvate, formate, $\mathrm{H}_{2} / \mathrm{CO}_{2}$ and $\mathrm{CO} / \mathrm{CO}_{2}$. The acetate/substrate ratios obtained with C. scatologenes DSM $757^{\mathrm{T}}$ were lower than those obtained with strain SL1 (Table 1). TSB medium lacked supplemental $\mathrm{CO}_{2}$ and the recovery of reductant on TSB medium was less than that obtained with U medium for both C. scatologenes DSM $757^{\mathrm{T}}$ and strain SL1 (Table 2). In addition, $\mathrm{H}_{2}$ was produced when both strains were cultivated in TSB medium but not in $\mathrm{U}$ medium; the production of $\mathrm{H}_{2}$ was greater with C. scatologenes DSM $757^{\mathrm{T}}$ (Table 2). Vanillate was O-demethylated and decarboxylated to catechol, yielding acetate.

$\mathrm{H}_{2}$ and $\mathrm{CO}$ were consumed very slowly by $C$. scatologenes DSM $757^{\mathrm{T}}$ and growth on these substrates was negligible (see Table 1). Nonetheless, consumption of $\mathrm{H}_{2}$ and $\mathrm{CO}$ was concomitant to the production of acetate. Despite the difficulty in demonstrating the growth of C. scatologenes DSM $757^{\mathrm{T}}$ under $\mathrm{H}_{2}$ and $\mathrm{CO}$, and despite the decreased acetate/substrate ratios of C. scatologenes DSM $757^{\mathrm{T}}$, CO dehydrogenase, hydrogenase and formate dehydrogenase activities in cell extracts of C. scatologenes DSM $757^{\mathrm{T}}$ were similar to those of strain SL1 (Table 3).

\section{DISCUSSION}

C. scatologenes has been isolated from soil and other habitats and is named for its production of skatole, an organic compound (3-methyl-1-H-indole) that has a dung-like odour (Weinberg \& Ginsbourg, 1927; Smith, 1975). Strain SL1 produced a similar odour. $C$. scatologenes is described as an obligately anaerobic, Gram-positive, spore-forming, motile rod with a length of 3-21 $\mu \mathrm{m}$ (Holdeman et al., 1977). As reported for other clostridial cells (Cato et al., 1986), cells of strain SL1 stained weakly Gram-negative; however, thin sections did not reveal an outer membrane (Fig. 1d). The extended length of strain SL1 observed by light microscopy was likely due to predivisional elongation of the cells (Fig. 1e).

C. scatologenes has been characterized as both a saccharolytic and proteolytic fermenter that produces acetate and butyrate as main products and caproate, formate, propionate, iso-valerate and valerate as trace products (Holdeman et al., 1977). However, the capacity of $C$. scatologenes to grow acetogenically on 


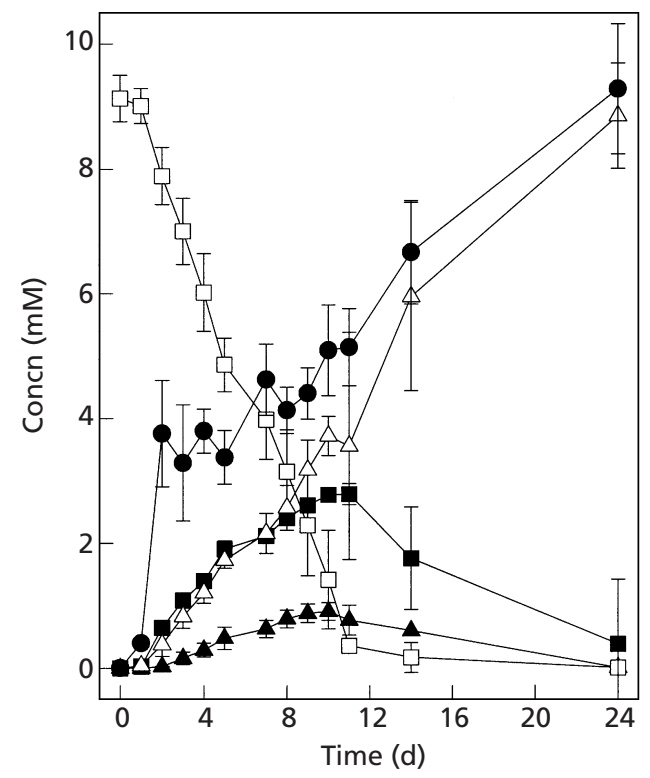

Fig. 3. Substrate/product profiles of strain SL1 cultivated in $U$ medium supplemented with ferulate. Data are the means ( $\pm S D$ ) of three replicates. $\square$, Ferulate; $\square$, hydroferulate; $\triangle$, hydrocaffeate; $\boldsymbol{\Delta}$, caffeate; $\boldsymbol{0}$, acetate. In controls lacking additional substrate, the concentration of acetate was approximately $2 \cdot 2 \mathrm{mM}$.

$\mathrm{C}_{1}$ compounds like $\mathrm{H}_{2} / \mathrm{CO}_{2}, \mathrm{CO} / \mathrm{CO}_{2}$, formate or O-methyl groups of aromatic compounds has not been reported in the past. The substrate utilization capacities of C. scatologenes DSM $757^{\mathrm{T}}$ and strain SL1 were similar; however, the capacity of both strains to utilize $\mathrm{H}_{2}$ and $\mathrm{CO}$ was minimal and difficult to sustain. Neither strain grew autotrophically (i.e. under $\mathrm{H}_{2} / \mathrm{CO}_{2}$ without yeast extract). Many other acetogens (e.g. Ruminococcus productus and Ruminococcus hansenii; Bernalier et al., 1996) also display weak autotrophic capacities. In microcosms prepared from sediments of this cold, acidic coal mine pond, acetogens are capable of consuming $\mathrm{H}_{2}$ at $12{ }^{\circ} \mathrm{C}$ (Küsel et al., 1998). The isolation of strain SL1, an acetogen that is capable of growth over broad temperature and $\mathrm{pH}$ ranges, corroborates the possibility that acetogenesis is an ongoing process in this ecosystem. Relatively little information is available on the growth of acetogens under low $\mathrm{pH}$ and low temperature conditions (Phelps \& Zeikus, 1984; Kotsyurbenko et al., 1993; Wiegel, 1994).

Both strain SL1 and C. scatologenes DSM $757^{\mathrm{T}}$ utilized various side chains of aromatic compounds. Many acetogens can utilize O-methyl groups of aromatic compounds (Frazer, 1994) or reduce the carboncarbon double bond of acrylate side chains of aromatic compounds (Drake et al., 1994). Decarboxylation of benzoate derivatives has also been reported for the thermophilic acetogens Moorella thermoacetica (Hsu et al., 1990) and Moorella thermoautotrophica (Fröstl et al., 1996). Small amounts of butyrate were formed by strain SL1. Butyrate, together with acetate, is also produced by the acetogen Eubacterium limosum (Sharak-Genthner et al., 1981) and closely related 'Butyribacterium methylotrophicum' (Zeikus et al., 1980). C. scatologenes DSM $757^{\mathrm{T}}$ also produced small amounts of $\mathrm{H}_{2}$ in TSB medium supplemented with sugars; the production of $\mathrm{H}_{2}$ by $C$. scatologenes grown on peptone/yeast extract/glucose (PYG) broth has been reported (Holdeman et al., 1977). Many acetogens, including $M$. thermoacetica (Martin et al., 1983; Daniel et al., 1990), produce trace levels of $\mathrm{H}_{2}$. The loss of reductant as $\mathrm{H}_{2}$ by $C$. scatologenes DSM $757^{\mathrm{T}}$ in TSB medium indicates that (i) the flow of reductant to the acetyl-CoA pathway can be suppressed by a rich organic medium or (ii) certain conditions induce a very efficient $\mathrm{H}_{2}$-producing hydrogenase. Significant levels of $\mathrm{H}_{2}$ were not produced by strain SL1, indicating that strain SL1 and C. scatologenes DSM $757^{\mathrm{T}}$ are not physiologically identical.

That $C$. scatologenes is an acetogen is consistent with its phylogenetic branching adjacent to the acetogen

Table 3. Enzyme activities in cell extracts of strain SL1 and C. scatologenes DSM 757 cultivated on various substrates

Cells were grown in U medium supplemented with $10 \mathrm{mM}$ substrate (as indicated) and harvested in late exponential phase.

\begin{tabular}{|c|c|c|c|c|}
\hline \multirow[t]{2}{*}{ Organism } & \multirow{2}{*}{$\begin{array}{l}\text { Growth } \\
\text { substrate }\end{array}$} & \multicolumn{3}{|c|}{ Specific activity $\left.[\mathrm{U} \text { (mg protein) })^{-1}\right]^{*}$} \\
\hline & & CODH & $\mathrm{H}_{2}$ ase & FDH \\
\hline Strain SL1 & $\begin{array}{l}\text { Fructose } \\
\text { Vanillate } \\
\text { Ethanol }\end{array}$ & $\begin{array}{l}0 \cdot 27 \pm 0 \cdot 15 \\
3 \cdot 76 \pm 1 \cdot 42 \\
6 \cdot 26 \pm 2 \cdot 11\end{array}$ & $\begin{array}{r}3.02 \pm 0.87 \\
8.70 \pm 0.76 \\
23.13 \pm 1 \cdot 86\end{array}$ & $\begin{array}{c}0.02 \pm 0.01 \\
0.09 \pm 0.02 \\
0.42 \pm 0.17\end{array}$ \\
\hline C. scatologenes & $\begin{array}{l}\text { Vanillate } \\
\text { Ethanol }\end{array}$ & $\begin{array}{l}2.48 \pm 0.87 \\
0.74 \pm 0.05\end{array}$ & $\begin{array}{r}9 \cdot 45 \pm 0 \cdot 26 \\
26 \cdot 69 \pm 2 \cdot 13\end{array}$ & $\begin{array}{l}0 \cdot 12 \pm 0 \cdot 02 \\
1 \cdot 01 \pm 0 \cdot 21\end{array}$ \\
\hline
\end{tabular}

* Values are the mean $( \pm \mathrm{SD})$ of three replicates. Control values were approximately $0 \cdot 00 \pm 0 \cdot 01 \mathrm{U}$ $(\mathrm{mg} \text { protein })^{-1}$. CODH; $\mathrm{CO}$ dehydrogenase; $\mathrm{H}_{2}$ ase, hydrogenase; $\mathrm{FDH}$, formate dehydrogenase. 


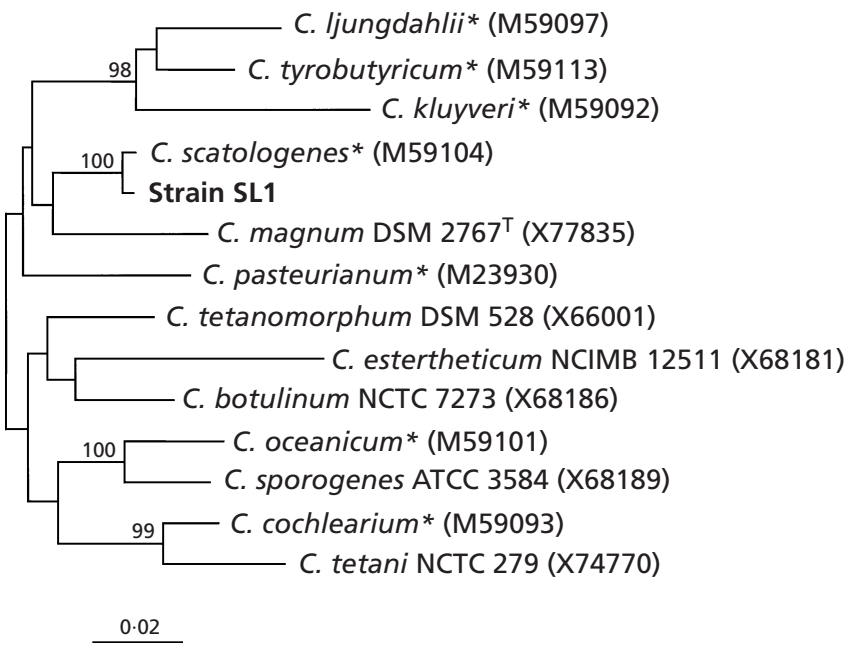

Fig. 4. Dendrogram showing the phylogenetic position of strain SL1 (based on analysis of the 16S rRNA gene). Scale bar, $12 \mathrm{nt}$ substitutions per $100 \mathrm{nt}$. Numbers at the branching points refer to bootstrap values $>$ than $95 \%$ (500 resamplings). *, Strain numbers not available. Accession numbers of $16 \mathrm{~S}$ rRNA gene sequences are given in parentheses.

Clostridium magnum (Fig. 4). C. magnum was initially isolated as a heterotrophic acetogen (Schink, 1984) but was later shown to be capable of lithotrophic growth under $\mathrm{H}_{2} / \mathrm{CO}_{2}$ (Bomar et al., 1991). The acetogen $M$. thermoacetica was also isolated as an obligate heterotroph (Fontaine et al., 1942) and later shown to grow autotrophically under $\mathrm{H}_{2} / \mathrm{CO}_{2}$ and $\mathrm{CO} / \mathrm{CO}_{2}$ (Daniel et al., 1990). Likewise, the acetogen Clostridium formicoaceticum was thought to be incapable of autotrophic growth (Andreesen et al., 1970) until it was shown to grow autotrophically under $\mathrm{CO} / \mathrm{CO}_{2}$ (Lux \& Drake, 1992). In general, most acetogens grow very poorly under $\mathrm{H}_{2} / \mathrm{CO}_{2}$, in part because of the thermodynamic constraints of reducing $\mathrm{CO}_{2}$ to the $\mathrm{CO}$ level on the carbonyl branch of the acetyl-CoA pathway (Drake, 1994). In addition, despite the obligatory occurrence of $\mathrm{CO}$ dehydrogenase in acetogens, some acetogens cannot grow in the presence of $\mathrm{CO}$ [e.g. Thermoanaerobacter (Acetogenium) kivui; Daniel et al., 1990]. Thus, it is not surprising that the capacity of $C$. scatologenes to grow acetogenically in the presence of $\mathrm{H}_{2}$ or $\mathrm{CO}$ has thus far gone undetected and is difficult to maintain. That strain SL1 tends to lose its ability to efficiently utilize $\mathrm{H}_{2}$ or $\mathrm{CO}$ indicates that $C$. scatologenes loses this lithotrophic capacity upon prolonged cultivation in the laboratory.

The acetogenic capacity of certain clostridial species may be the result of (i) divergent evolution from an ancestral species or (ii) the independent occurrence of the acetyl-CoA pathway among different clostridial groups (Tanner \& Woese, 1994). The capacity to fix $\mathrm{CO}_{2}$ via the acetyl-CoA pathway is common to other anaerobic prokaryotes like methanogens (Fuchs, 1994) and the similarity between the metal centres and the reactions catalysed by both acetogenic and methanogenic bacteria might be of evolutionary significance (Ragsdale, 1994). It is interesting to note that the butyrate fermenter Clostridium pasteurianum is not a close phylogenetic relative of $C$. scatologenes but nonetheless can consume (i.e. oxidize) $\mathrm{CO}$ during growth (Thauer et al., 1974) and has a nickelcontaining CO dehydrogenase (Diekert et al., 1979; Drake 1982b). The nickel-containing CO dehydrogenase (i.e. acetyl-CoA synthase) of acetogens is of central importance to the acetyl-CoA pathway (Wood \& Ljungdahl, 1991; Ragsdale, 1994). The results of this study indicate that clostridial species not previously known to be acetogens may nonetheless be capable of engaging the acetyl-CoA pathway under certain conditions. Given the wide distribution of acetogens in distantly related genera (Collins et al., 1994; Willems \& Collins, 1995, 1996), this possibility exists for non-clostridial anaerobes as well.

\section{ACKNOWLEDGEMENTS}

The authors thank Ulrike Mendrock and Ina Kramer for the phylogenetic analysis of strain SL1, Rita Grotjahn and Rita Schineis for preparation of the electron micrographs and Carola Matthies for critical reading of the manuscript. This study was supported by the German Ministry of Education, Science, Research and Technology (0339476 B).

\section{REFERENCES}

Andreesen, J. R., Gottschalk, G. \& Schlegel, H. G. (1970). Clostridium formicoaceticum nov. spec. isolation, description and distinction from $C$. aceticum and C. thermoaceticum. Arch Microbiol 72, 154-174.

Bernalier, A., Willems, A., Leclerc, M., Rochet, V. \& Collins, M. D. (1996). Ruminococcus hydrogenotrophicus sp. nov., a new $\mathrm{H}_{2} / \mathrm{CO}_{2}$-utilizing acetogenic bacterium isolated from human feces. Arch Microbiol 166, 176-183.

Blenden, D. C. \& Goldberg, H. S. (1965). Silver impregnation stain for Leptospira and flagella. J Bacteriol 89, 899-900.

Bomar, M., Hippe, H. \& Schink, B. (1991). Lithotrophic growth and hydrogen metabolism by Clostridium magnum. FEMS Microbiol Lett 83, 347-350.

Bradford, M. M. (1976). A rapid and sensitive method for the quantitation of microgram quantities of protein utilizing the principle of protein-dye binding. Anal Biochem 72, 248-254.

Caccavo, F., Jr, Lonergan, D. J., Lovley, D. R., Davis, M., Stolz, J. F. \& Mclnerney, M. J. (1994). Geobacter sulfurreducens sp. nov., a hydrogen- and acetate-oxidizing dissimilatory metal-reducing microorganism. Appl Environ Microbiol 60, 3752-3759.

Cashion, P., Holder-Franklin, M. A., McCully, J. \& Franklin, M. (1977). A rapid method for the base ratio determination of bacterial DNA. Anal Biochem 81, 461-466.

Cato, E. P., George, W. L. \& Fiengold, S. M. (1986). Genus Clostridium Prazmowski 1880, 23 ${ }^{\mathrm{AL}}$. In Bergey's Manual of Systematic Bacteriology, vol. 2, pp. 1141-1200. Edited by P. H. A. Sneath, N. S. Mair, M. E. Sharpe \& J. G. Holt. Baltimore: Williams \& Wilkins.

Clark, G. (1973). Staining Procedures used by the Biological Stain Commission, 3rd edition. Baltimore: Williams \& Wilkins.

Collins, M. D., Lawson, P. A., Willems, A., Cordoba, J. J., 
Fernandez-Garayzabal, J., Garcia, P., Cai, J., Hippe, H. \& Farrow, J. A. E. (1994). The phylogeny of the genus Clostridium: Proposal of five new genera and eleven new species combinations. Int $J$ Syst Bacteriol 44, 812-826.

Daniel, S. L., Hsu, T., Dean, S. I. \& Drake, H. L. (1990). Characterization of the $\mathrm{H}_{2}$ - and $\mathrm{CO}$-dependent chemolithotrophic potentials of the acetogens Clostridium thermoaceticum and Acetogenium kivui. J Bacteriol 172, 4464- 4471.

DeSoete, G. (1983). A least squares algorithm for fitting additive trees to proximity data. Psychometrika 48, 621-626.

Diekert, G. B., Graf, E. G. \& Thauer, R. K. (1979). Nickel requirement for carbon monoxide dehydrogenase formation in Clostridium pasteurianum. Arch Microbiol 122, 117-120.

Drake, H. L. (1982a). Demonstration of hydrogenase in extracts of the homoacetate-fermenting bacterium Clostridium thermoaceticum. J Bacteriol 150, 702-709.

Drake, H. L. (1982b). Occurrence of nickel in carbon monoxide dehydrogenase from Clostridium pasteurianum and Clostridium thermoaceticum. J Bacteriol 149, 561-566.

Drake, H. L. (1994). Acetogenesis, acetogenic bacteria, and the acetyl-CoA 'Wood/Ljungdahl' pathway: past and current perspectives. In Acetogenesis, pp. 1-15. Edited by H. L. Drake. New York: Chapman and Hall.

Drake, H. L., Daniel, S. L., Matthies, C. \& Küsel, K. (1994). Acetogenesis: reality in the laboratory, uncertainty elsewhere. In Acetogenesis, pp. 273-302. Edited by H. L. Drake. New York: Chapman and Hall.

Felsenstein, J. (1985). Confidence limits on phylogenies: an approach using the bootstrap. Evolution 39, 783-789.

Felsenstein, J. (1993). PHYLIP (Phylogeny Inference Package), version 3.5.1. Seattle: Department of Genetics, University of Washington.

Fontaine, F. E., Peterson, W. H., McCoy, E., Johnson, M. J. \& Ritter, G. J. (1942). A new type of glucose fermentation by Clostridium thermoaceticum n. sp. J Bacteriol 43, 701-715.

Frazer, A. C. (1994). O-demethylation and other transformations of aromatic compounds by acetogenic bacteria. In Acetogenesis, pp. 445-483. Edited by H. L. Drake. New York: Chapman and Hall.

Fröstl, J. M., Seifritz, C. \& Drake, H. L. (1996). Effect of nitrate on the autotrophic metabolism of the acetogens Clostridium thermoautotrophicum and Clostridium thermoaceticum. $J$ Bacteriol 178, 4597-4603.

Fuchs, G. (1994). Variations of the acetyl-CoA pathway in diversely related microorganisms that are not acetogens. In Acetogenesis, pp. 507-520. Edited by H. L. Drake. New York: Chapman and Hall.

Holdeman, L. V., Cato, E. P. \& Moore, W. E. C. (1977). Anaerobe Laboratory Manual, 4th edn, pp. 1-156. Blacksburg: Anaerobe Laboratory, Virginia Polytechnic Institute and State University.

Hsu, T., Daniel, S. L., Lux, M. F. \& Drake, H. L. (1990). Biotransformations of carboxylated aromatic compounds by the acetogen Clostridium thermoaceticum: generation of growthsupportive $\mathrm{CO}_{2}$ equivalents under $\mathrm{CO}_{2}$-limited conditions. $J$ Bacteriol 172, 212-217.

Hungate, R. E. (1969). A roll tube method for cultivation of strict anaerobes. Methods Microbiol 3B, 117-132.

Johnson, J. L. \& Francis, B. S. (1975). Taxonomy of the clostridia: ribosomal nucleic acid homologies among the species. $J$ Gen Microbiol 88, 229-244.

Kotsyurbenko, O. R., Nozhevnikova, A. N. \& Zavarzin, G. A.
(1993). Methanogenic degradation of organic matter by anaerobic bacteria at low temperature. Chemosphere 27, $1745-1761$.

Kuhner, C. H., Frank, C., Grießhammer, A., Schmittroth, M., Acker, G., Gößner, A. \& Drake, H. L. (1997). Sporomusa silvacetica sp. nov., an acetogenic bacterium isolated from aggregated forest soil. Int J Syst Bacteriol 47, 352-358.

Küsel, K. \& Drake, H. L. (1995). Effects of environmental parameters on the formation and turnover of acetate in forest soils. Appl Environ Microbiol 61, 3667-3675.

Küsel, K., Dorsch, T. \& Stackebrandt, E. (1998). Characterization of microbial communities and of two isolates from sediments of acidic coal mine ponds. In Abstracts of the 98th Annual Meeting of the American Society for Microbiology 1998, abstract N-89, p. 380. Washington, DC: American Society for Microbiology.

Laemmli, U. K. (1970). Cleavage of structural proteins during the assembly of the head of bacteriophage T4. Nature 227, 680-685.

Lux, M. F. \& Drake, H. L. (1992). Re-examination of the metabolic potentials of the acetogens Clostridium aceticum and Clostridium formicoaceticum: chemolithoautotrophic and aromatic-dependent growth. FEMS Microbiol Lett 95, 49-56.

Maidak, B. L., Olsen, G. L, Larsen, N., Overbeek, R., McCaughey, M. J. \& Woese, C. R. (1996). The Ribosomal Database Project (RDP). Nucleic Acids Res 24, 82-85.

Martin, D. R., Lundie, L. L., Kellum, R. \& Drake, H. L. (1983). Carbon monoxide-dependent evolution of hydrogen by the homoacetate-fermenting bacterium Clostridium thermoaceticum. Curr Microbiol 8, 337-340.

Mesbah, M., Premachandran, U. \& Whitman, B. (1989). Precise measurement of the $\mathrm{G}+\mathrm{C}$ content of deoxyribonucleic acid by high-performance liquid chromatography. Int $J$ Syst Bacteriol 39, 159-167.

Phelps, T. J. \& Zeikus, J. G. (1984). Influence of $\mathrm{pH}$ on terminal carbon metabolism in anoxic sediments from a mildly acidic lake. Appl Environ Microbiol 48, 1088-1095.

Ragsdale, S. W. (1994). CO dehydrogenase and the central role of this enzyme in the fixation of carbon dioxide by anaerobic bacteria. In Acetogenesis, pp. 88-126. Edited by H. L. Drake. New York: Chapman and Hall.

Rainey, F. A., Ward-Rainey, N., Kroppenstedt, R. M. \& Stackebrandt, E. (1996). The genus Nocardiopsis represents a phylogenetically coherent taxon and a distinct actinomycete lineage; proposal for Nocardiopsaceae fam. nov. Int J Syst Bacteriol 46, 1088-1092.

Reynolds, E. S. (1963). The use of lead citrate at high $\mathrm{pH}$ as an electron opaque stain in electron microscopy. J Cell Biol 7, 208.

Saitou, N. \& Nei, M. (1987). The neighbor-joining method: a new method for reconstructing phylogenetic trees. Mol Biol Evol 4, 406-425.

Schink, B. (1984). Clostridium magnum sp. nov., a non-autotrophic homoacetogenic bacterium. Arch Microbiol 137, 250-255.

Schink, B. (1994). Diversity, ecology, and isolation of acetogenic bacteria. In Acetogenesis, pp. 273-302. Edited by H. L. Drake. New York: Chapman and Hall.

Sharak-Genthner, B. R., Davis, C. L. \& Bryant, M. P. (1981). Features of rumen and sewage sludge strains of Eubacterium limosum, a methanol- and $\mathrm{H}_{2}-\mathrm{CO}_{2}$-utilizing species. Appl Environ Microbiol 42, 12-19.

Smith, L. D. S. (1975). Common mesophilic anaerobes, including Clostridium botulinum and Clostridium tetani, in 21 soil specimens. Appl Environ Microbiol 29, 590-594. 
Tamura, H., Goto, K., Yotsuyanagi, T. \& Nagayama, M. (1974). Spectrophotometric determination of iron(II) with $1,10-$ phenanthroline in the presence of large amounts of iron(III). Talanta 21, 314-318.

Tanner, R. S. \& Woese, C. R. (1994). A phylogenetic assessment of the acetogens. In Acetogenesis, pp. 254-272. Edited by H. L. Drake. New York: Chapman and Hall.

Thauer, R. K., Fuchs, G., Käufer, B. \& Schnitker, U. (1974). Carbonmonoxide oxidation in cell-free extracts of Clostridium pasteurianum. Eur J Biochem 45, 343-349.

Traub, W. H., Acker, G. \& Kleber, I. (1976). Ultrastructural surface alterations of Serratia marcescens after exposure to polymyxin B and/or fresh human serum. Chemotherapy 22 , 104-113.

Valentine, R. C., Shapiro, B. M. \& Stadtman, E. R. (1968). Regulation of glutamine synthetase. XII. Electron microscopy of the enzyme from Escherichia coli. Biogeochemistry 7, 2143-2152.

Weinberg, M. \& Ginsbourg, B. (1927). Données récéntes sur les microbes anaérobies et leur role en pathologie, pp. 1-291. Paris: Masson et Cie.
Wiegel, J. (1994). Acetate and the potential of homoacetogenic bacteria for industrial applications. In Acetogenesis, pp. 484-504. Edited by H. L. Drake. New York: Chapman and Hall.

Willems, A. \& Collins, M. D. (1995). Phylogenetic placement of Dialister pneumosintes (formerly Bacteroides pneumosintes) within the Sporomusa subbranch of the Clostridium subphylum of the gram-positive bacteria. Int J Syst Bacteriol 45, 403-405.

Willems, A. \& Collins, M. D. (1996). Phylogenetic relationships of the genera Acetobacterium and Eubacterium sensu stricto and reclassification of Eubacterium alactolyticum as Pseudoramibacter alactolyticus gen. nov., comb. nov. Int J Syst Bacteriol 46, 1083-1097.

Wood, H. G. \& Ljungdahl, L. G. (1991). Autotrophic character of acetogenic bacteria. In Variations in Autotrophic Life, pp. 201-255. Edited by J. M. Shively \& L. L. Barton. San Diego: Academic Press.

Zeikus, J. G., Lynd, L. H., Thompson, T. E., Krzycki, J. A., Weimer, P. J. \& Hegge, P. W. (1980). Isolation and characterization of a new, methylotrophic acidogenic anaerobe, the Marburg strain. Curr Microbiol 3, 381-386. 